\title{
"Co zla již natropila tato domnělá ideovost!" Změna kritických postojů Vladimíra Helferta po přesídlení z Prahy do Brna
}

\section{"What an Evil Has this Ideological Bias Already Done!" \\ The Change of Vladimír Helfert's Critical Attitudes After Moving from Prague to Brno}

Jindřiška Bártová / bartova@jamu.cz

Hudební fakulta Janáčkovy akademie múzických umění, Brno, CZ

\begin{abstract}
After 1911, tendencies appeared in the Czech music culture to eliminate Antonín Dvořák. They were initiated by Zdeněk Nejedlý. As Nejedlý was not able to support his opinions by musical analysis, he created his own hierarchy of values based on ideological character of a musical composition. Vladimír Helfer, a Nejedly's follower, adopted this opinion and became the protagonist of "Dvořák Affair". He made a contribution with a theory on low Czech musicianship of the Counter-Reformation period - so-called "dark ages" - and labelled Dvořák as a representative of this musicianship. After war Vladimír Helfert moved from Prague to Brno and the new environment changed him completely. He totally reassessed his opinion of Dvoŕák and the ideological character of music and in 1935 published opinions opposite to those he held twenty years ago, including a lamentation "what an evil has this ideological bias already done".
\end{abstract}

\section{Key words}

Vladimír Helfert, Zdeněk Nejedlý, Antonín Dvořák, ideological bias 
Tento příspěvek mîrí do doby před sto lety, kdy se v české hudební kultuře objevily snahy eliminovat z ní jednoho z jejích největších tvůrců - Antonína Dvořáka, případně i těch, kteří se k němu hlásili, zejména Josefa Suka a Leoše Janáčka.

Iniciátorem těchto snah byl Zdeněk Nejedlý. Rodák z Litomyšle a zapálený obdivovatel svého „spolurodáka“ Bedřicha Smetany a také jistě obdivovatel svého otce Romana Nejedlého, který v Litomyšli působil třicet let a patřil k místní kulturní elitě (ř́́dil místní pěvecký spolek Vlastimil, byl ředitelem kůru a varhaníkem a nakladatelem hudebních děl - i vlastních, z nichž zručně napsané komické výstupy jako Sezeni městské rady v Mrkvanticích dosáhly široké známosti). Inspirativní působení rodiny, v níž Zdeněk Nejedlý žil do svých osmnácti let, jej nepochybně podněcovalo k nastartování a rozvíjení obdobné široce pojímané činnosti v oblasti hudby. Oproti otci však měl handicap v tom, že jeho hudební znalosti nebyly bezpečné (korigujeme jeho výrok v časopise Smetana, v němž tvrdí pravý opak ${ }^{1}$ ). Kdykoliv se pokusil o hudební analýzu, dopouštěl se elementárních chyb, jež mu byly vzhledem $\mathrm{k}$ jeho velké neoblíbenosti vzápětí vytýkány. ${ }^{2}$ Zdeněk Nejedlý si proto vytvořil svoji hierarchii hodnot, která byla založená na ideji hudebního díla. Ideu mohl popsat i bez sebemenších hudebních znalostí a mohl s její pomocí rozsuzovat, co je dobré a co špatné.

Oproti svým nedostatkům měl Nejedlý jednu nepopiratelnou přednost: byl to charismatický vůdce, jehož názory nadšeně přejímali jeho žáci a stoupenci. Právě ve druhém desetiletí 20. století jich v souvislosti s Nejedlého učitelským působením na Univerzitě Karlově znatelně přibývalo. Jako jednotlivci psali kritiky do tehdejších deníků a jako skupina se soustředili kolem nově založeného časopisu časopisu Smetana ${ }^{3}$. Patřili k nim hudební kritikové a redaktoři Artuš Rektorys a Hubert Doležil, estetikové Otakar Zich a Josef Bartoš, režisér Ferdinand Pujman, skladatel Karel Boleslav Jirák a další.

Mezi tyto pisatele se zařadil i Vladimír Helfert, o osm let mladší než jeho univerzitní učitel a pozdější švagr Zdeněk Nejedlý. Helfertovou parketou se stal „spor o Dvořáka“. Tento podivný jev souvisel s celosvětově připomínaným 70. výročím Dvořákova narození v roce 1911, během něhož skladatelovo dílo zaznívalo častěji a s úspěchem v evropských koncertních sálech, což vedlo $\mathrm{k}$ tomu, že se v německých recenzích objevilo heslo „více Dvořáka“. Tuto informaci přinesla Hudební revue na podzim 1912 s dodatkem: „Nikdo na celém světě nebyl provozováním skladeb mistrových dotčen nemile - až na skupinu kritikư, jejichž duchovním otcem jest prof. Nejedlý. Páni Dři Bartoš a Helfert upadli v pokrokové delirium.

1 Nejedlý ve své polemice s Václavem Štěpánem týkající se Nejedlého zdrcující kritiky Její pastorkyně napsal, že Štěpánův článek je důkazem ,jak málo vzdělaní, totiž jak málo hudebně vzdělaní jsou mnozí naši hudebníci, když nedovedou ani posouditi hudební kvalitu Pastorkyně. [...] Moje zkušenost jest trochu větší a také hudební znalosti poněkud bezpečnější (zvýraznila J. B.), abych se nechal klamati takovou chvilkovou náladou..." Smetana VII.,1917, s. 15.

2 Skladatel Ladislav Vycpálek např́klad v roce 1911 sumarizoval tyto Nejedlého nedostatky: „Dokázal jsem přesnĕ, že nedovedete analyzovati nejjednoduřši modulace, že si pletete enharmoniku s chromatikou, že nedovedete ani rozebrati skladbu tak motivicky jednoduchou, jako jest Smetanưv Furiant, že neznáte dĕjiny harmonie (myslíte, že zvětšený terckvartakord se datuje od Wagnera), že nerozumite pořádně ani české deklamaci." (VYCPÁLEK, Ladislav. Jak se pan profesor Nejedlý učil harmonii. Hudebni revue, roč. 4, č. 7, červenec 1911, s. 380.)

3 Stejnojmenný časopis vycházel v letech 1906-1907 jako orgán Hudebního odboru Umělecké besedy, jeho redaktorem byl Jan Branberger. Nový „hudební list“ Smetana, redigovaný Artušem Rektorysem, vyšel poprvé v listopadu 1910. 
Již u př́ležitosti loňského jubilea p. Dr. Bartoš ,připojil in marginem Dvořákova díla několik skromných poznámek; jichž špatně zakrytou tendencí bylo potírati Dvořáka jménem Smetanovým a snižiti jej takto umělecky i lidsky. [...] Téměr současně vyšel v České kultuře článek p. Dra. Helferta Více Dvořáka, v němž fakta posledni doby jsou vědomě falšována a na Dvořáka skonstruována [sic.] formule, aby jej učinila umělecky nemožným: Dvořák jest typ českého muzikanta, jak jej vytvořila protireformace, doba naši kulturni bidy; proti tomuto protikulturnimu muzikantstvi (Dvořák) stoji hudebni kultura (Smetana); proto heslo, Vice Dvořáka“znamená kulturni nebezpečr. Tendence stlačiti význam Dvořáki̊v vedle Smetany jest tak u obou kritiků shodna dokonale“.4

Projevy Bartoše a Helferta daly podnět k protestu českých hudebníků, který byl otištěn v pražských denících 15. prosince 1912 a později i v časopisech Hudební revue a Dalibor a jejž podepsalo 31 umělcủ. Byly mezi nimi osobnosti jako Rudolf Karel, Karel Kovařovic, Jaroslav Křička, Jan Kunc, Oskar Nedbal, Vítězslav Novák, František Ondř́íček, Josef Suk, Otakar Ševčík, Václav Talich, Hanuš Wihan a další, přičemž někteří z podepsaných, konkrétně František Ondříček, Karel Kovařovic, Josef Suk a Vilém Zemánek, připojili navíc ještě svůj vlastní komentář k neetickým způsobům, jimiž Bartoš a Helfert útočili. Avšak „oba páni měli tolik smělosti, že na protest odpověděli: ve věci samé směšnou výmluvou, že $k$,ostřejšim slovům ‘ byli, vyprovokováni ‘ príliš častým provozováním Dvořáka! "

Zatímco Josef Bartoš se po tomto incidentu poněkud stáhl a obhajoval „formou daleko slušnějši než dřive své přikré stanovisko “, Vladimír Helfert neustoupil ani o píd’ a své teze znovu zopakoval na přednášce pro Vědecký klub v Brně 28. 3. 1913. Nesla název $O$ českém muzikantstvi a Helfert se na ní pokoušel dokázat, že „̌̌eské muzikantstvi neni žádný samorostlý hudebni projev českosti, nýbrž že je ve svém jádru skrz naskrz nepưvodní, primitivické [sic.] (ve špatném slova smyslu) a naturalistické. Tento historický problém českého muzikantstvi byl mi v oné přednášce hlavni věci. Zde také jsem podal něco dosud nového, dosud nepovšimnutého. $K$ závěru přednášky jsem ukázal, jak se toto muzikantstvi, svým vznikem nepiovodni, jevi dosud $v$ dnešni hudbě. Zminil jsem, že Smetana proti muzikantstvi bojoval, že u Dvořáka se projevuje v úplné síle a upozornil, v čem jevi se u Janáčka. "7 Vznikla pak vzrušená debata, v níž se výrazně angažoval ředitel konzervatoře skladatel Jan Kunc, za což jej posléze Helfert ztrestal slovy „zasáhnuti Kuncovo bylo př́mo pathologickým úkazem o ,netheoretičnosti ${ }^{“}$ našich p. $t$. muzikantů. "8 Jan Kunc reagoval v Hudebni revui konstatováním, že „pan Helfert prokázal neznalost historie, nebot' nemohl reagovati na všechny zjevy, uvedené proti jeho hypotéze o , historickém problému českého muzikantství. Nepř́iemná byla úloha pana Součka, předsedy Vědeckého klubu brněnského, jenž snažil se zprostředkovati, aby řečnik, klubem pozvaný a představený jakožto ,nejlepši žák prof. Nejedlého', neodešel tak zcela poražen jako p. Helfert. “9

Ad vocem Dvořák připomeňme ještě jednu Helfertovu kritiku. Je z roku 1915, byla napsána po koncertu České filharmonie, na němž zazněly souborně Dvořákovy symfonické

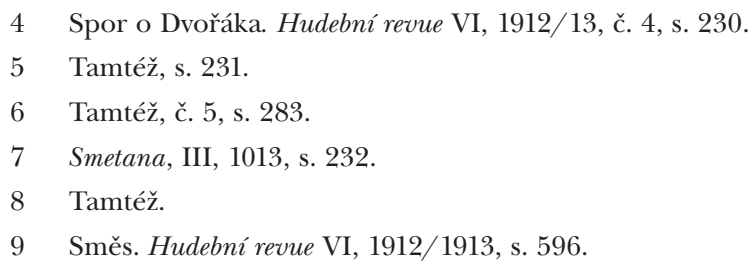


básně, a je další výstižnou ukázkou věcně nepodloženého, leč o to agresivnějšího způsobu argumentace: „Dvoŕákovy symfonické básně [...] ukázaly, jak dnes hudebně málo uspokojují. Jest věru až smutné, jak tato díla jsou hudebně chudá, věc, která ostatně př́mo souvisi s formální jich nemožnosti a nedostatkem básnické potence. Jest málo mist, která se povznášeji nad hudebně zcela bezvýznamné stránky, naplněné pouze prázdným šumem nebo planým zvukem. My však, kteři v hudbě hledáme něco více, kteři v ni vidime nejmohutnějši ř rě nevyslovitelných citü, odvracíme se od této hudby lhostejně. Ničeho nám nepovi. Tato hudba patři minulosti, přitomnost, tak těžká činy a tak přiliš vážná, prosévá tyto projevy nemilosrdnou, ale spravedlivou rukou. "10

Vedle Dvořáka mířily výpady skupiny stoupenců Zdeňka Nejedlého na většinu tehdejších osobností české hudby. V případu Josefa Suka, kterého skupina obvinila z vlastizrady, musel dokonce zasáhnout čestný soud Maffie. Útoky nejedlovců tedy nemohly minout ani Janáčka, na něhož se koncentrovaly od roku 1915 (na Šumařovo dítě) a hlavně v roce 1916 po premiéře Její pastorkyně (na niž napsal osmistránkovou od začátku do konce negativní recenzi Nejedlý). Janáček však reagoval rychle a vtipně: v listopadu 1917 odřekl předplatné časopisu Smetana a v prosinci napsal do Lidových novin fejeton, v němž uvádí jména svých kritiků ve snadno dešifrovatelném nelichotivém tvaru: „V hrozném strachu před nejedlým Helfertem, nemilosrdným kritikem měsičním, hledám doklady z literatury hudebni. Což na slova ,bliž je boži den ' a ,začiná se den Páně - to vystačím: vždyt' jsem z varhanické školy. Na husity XV. stoleti - to už půjde hưr̆. Ale z těch dávných dob máme už Šárku Fibichovu, Libuši Smetanovu a pomoc blizkou toho, kdo tam doležil a harmonizoval husitské zpězy “ (zvýrazněno Janáčkem). ${ }^{11}$

Po necelém roce už byla situace jiná, „nemilosrdný kritik měsíční nejedlý Helfert“ přesídlil z Prahy do Brna a zcela se změnil. Díky jinému prostředí a tudíž osamostatnění se vůči švagrovi, díky jiné společenské situaci po ukončení 1. světové války a především díky praktickému poznávání hudby a jejích zákonitostí poté, co založil a vedl Orchestrální sdružení, reviduje svá předchozí stanoviska. Zásadně přehodnocuje svůj názor na Dvořáka, na Janáčka (o němž začíná psát monografii) i na další skladatele a postupně dospívá k názorům zcela opačným, než byly ty, jež zastával pod vlivem Nejedlého v Praze. A dostává se dokonce do pozice, kdy kritizuje jiného pisatele za tytéž názory, které sám kdysi zastával: ve 30. letech se v Praze stal bojovným stoupencem názorů blízkých Zdeňku Nejedlému Bedřich Bělohlávek, který v časopise Sobota vyslovil námitky proti Helfertově rozhlasové přednášce proslovené v lednu 1935 Co dalo Československo světu v hudbě. Vladimír Helfert na ně odpověděl zásadní úvahou otištěnou v brněnském Indexu, kterou vzápětí převzala i Hudebni revue: „Bělohlávek děli hudbu na ,ideovou“ a na neideovou. K neideové z české hudby počíá Dvořáka a jeho školu, z cizich Strausse, Debussyho, Schönberga, Stravinského , a jiné. Vysloveně ideovým je mu Smetana, Fibich, Zich a zvláště Ot. Jeremiáš, z cizich Wagner a Mahler. A tím bychom byli hotovi s Bèlohlávkovým názorem na českou hudbu a na jeji pomér $k$ hudbě světové. Na proni pohled je patrno, jak úzký je to názor, jak ochuzuje naši hudbu o celé tvưrči komplexy, nehledě $k$ povážlivě zúženému pohledu na hudbu světovou. Co zla již natropila tato domnělá ideovost! Jejím jménem se vylučovaly z české kultury pozoruhodné tvưrči zjevy,

10 Smetana SV, 1915, s. 81.

11 Fejeton Výlety páně Broučkouy vyšel v Lidových novinách 23. 12. 1917. 
jejim jménem se zveličovali skladatelé bůhvikolikátého řádu. Vidět v ,ideovosti vlastni podstatu a tedy kriterion hudby je dědictvi romantické ideologie, kdy v době programnosti hudebni a v době symfonické básně za nejvyšši úkol hudby platilo sdělováni, vyjadřováni ideji. Dnes věru by bylo již nejuýše na čase, aby ti, kteři stále se nemohou vymanit ze zajeti tohoto romantického názoru na hudbu, si trochu promyslili estetické základy tohoto názoru a aby si řekli: Sdělováni idejí, jakož i každé mimohudebni predstavy hudbou, rozumějte čistě hudebnimi prostředky, je nemožné. Nemohu proto měrit a hodnotit hudbu něčim, čeho ve své podstatě neni schopna. "12

$\mathrm{V}$ tomto překvapivě věcném duchu pokračuje Helfert i dále. Objasňuje, že skladatel sice může nějakou ideu nebo city vyjádřit, že však záleží na tom, jak to vyjádří a co z toho může posluchač poznat, a zdůrazňuje, že ve většině případů má skladatel představy ryze hudební. I tehdy, kdy skladatel chce zhudebnit nějakou mimohudební představu, musí se mu tato představa přetavit do hudební myšlenky - motivu, tématu, barvy, celkové koncepce - a v tom okamžiku se ona mimohudební představa stává „pouhým inspiračním zdrojem a prestává být něč́m rozhodujicím pro hodnotu dila. Nebot' od toho okamžiku o hodnotě dila rozhoduje předevšim a zatím výhradně otázka čisté hudebni struktury.[...] Tedy nikoliv ideovost, nýbrž tato hudebni struktura je mi prvnim a jedině spolehlivým kriteriem. V uměni právě nezáleži ani tak na tom, co se vyjadřuje, nýbrž jak se to vyjadřuje. " 13

Helfert zdůrazňuje, že idea je v hudbě samé nepoznatelná a že tudíž nemůže určovat hodnotu díla. Jako příklad uvádí Smetanovu Vltavu, která podle něj není tak dokonalým dílem proto, že vyjadřuje ideu vlasti, nýbrž proto, že roste z původních hudebních myšlenek a že se v ní „spojuje přísná stavebnost s tvưrči vášní. Že Smetana pak bral inspiračni podnět $k$ tomuto hudebněvelikému dílu z nadosobni ideje vlasti a národa, zvyšuje sice tuto zjištěnou hudebni hodnotu, ale nemohlo by ji nikdy nahradit!" "14 A na základě těchto úvah dospívá Vladimír Helfert k závěrům, které jsou absolutně odlišné od jeho původních názorů deklarovaných v okruhu pražské skupiny stoupenců Zdeňka Nejedlého, a které posléze učinily z Helferta respektovanou kritickou osobnost: „Z toho vyplývá pro hudebni kritiku: Posuzovat jednotlivé zjevy tvưrčí nebo celý vývoj podle ideovosti neznamená nic jiného než zcela subjektivní, náladovou náhodnost. Nemũže-li hudba sdělit jednoznačně svými prostředky mimohudebni inspiračni zdroje, nemohu-li tedy poznat z hudby samé tyto podněty, $k$ nimž by patřily také ideje, jak mohu tvrdit, že tato hudba je ideová, nebo neideová? Je např. Beethoven ideový? Je Mozart ideový? Je-li Wagner ideový, proč neni napr. Brahms ideový? Proč neni ideový Dvořák, je-li ideový Fibich? Pokuste se dát odpověd’ k těmto otázkám, majice na paměti estetické a noetické základy, jichž jsme se zde dotkli, a uvidíte, jak všechno to mluveni o ideovosti v hudbě je náhodné, neodpovědné a koneckoncư nicotné. V hudbě platí jedna ideovost: je to ideovost čistě hudebni. Nová hudebni myšlenka, nové jeji domyšleni, dotvořováni podle podivuhodných zákonu hudebnich, ono zákonité hudebni pásmo, rostouci z hudebni myšlenky a do hudebnich myšlenkových systémů - neni-liž v tom pravá hudebni ideovost? Neníliž v tom, absolutní myšlenka'?

Mluvit o ideovosti v hudbě je velice pohodlné. Nemusíte rozumět hudbě ani za mák, nemusíte mít nutného pronikavého pohledu do procesů hudebniho myšleni a hudebni tvorby. Podle náhodného

12 Helfertova replika na úvahy o ideovosti časopise Index, citováno podle přetisku v Listech Hudebni matice 14, 1935, s. 300.

13 Tamtéž, s. 300.

14 Tamtéž. 
zdáni nebo podle nějakého třebas špatně pochopeného převzatého učeni mưžete touto ideovostí odpravovat tvưrči zjevy hlava nehlava. A ovšem můžete nafouknout průměrné zjevy v nadveličiny. A tak se dá vesele mluvit o hudbě a má to ještě tu výhodu, že to vyhliží velice duchaplně. " 15

Patrně není náhodou, že teprve poté, co Helfert dospěl k tomuto poznání, napsal nejen svá významná díla historická (Česká hudebni tvořivost před Smetanou, Dějiny hudby $v$ Československé republice ve francouzské a německé verzi), ale zejména díla pojednávající o tehdejší současnosti, jež neztratila dodnes svoji aktuálnost (Česká moderni hudba, Novák $i$ Ostrčil, řeč při promoci Josefa Suka na brněnské univerzitě a mnohá další).

English summary translation: Nora Hodečková

\section{Bibliography}

\section{Journals}

Hudebni revue. Praha: Umělecká beseda, 1908-1920.

Smetana: hudebni list. Praha, 1910-1917.

Listy Hudebni matice. V Praze: Hudební matice Umělecké besedy, 1921-1927.

\section{Monographs and studies}

BÁRTOVÁ, Jindřiška. Podivnosti kritických soudů v českém hudebním časopisectví na počátku století. Opus musicum, roč. 31, 1999, č. 4, s. 9-23.

PEČMAN, Rudolf. Vladimír Helfert. 1. vyd. Brno: Nadace Universitas Masarykiana, 2003, 232 s.

15 Helfertova replika na úvahy o ideovosti časopise Index citováno podle přetisku v Listech Hudební matice 14, 1935, s. 299-301. 